\title{
NOVO IMUNOTIPO DE UM GENÓTIPO VARIANTE DO VIRUS DA BRONQUITE INFECCIOSA (VBI) ISOLADO NO BRASIL DEFINIDO PELO TESTE DE PROTEÇÃO VACINAL COM A ESTIRPE MASSACHUSSETTS H120
}

(A NEW PROTECTOTYPE OF A VARIANT GENOTYPE OF INFECTIOUS BRONCHITIS VIRUS (IBV) ISOLATED IN BRAZIL DEFINED BY PROTECTION TEST WITH MASSACHUSETTS HI2O VACCINE STRAIN)

\section{F. S. FERNANDO ${ }^{1}$, R. M. DOS SANTOS ${ }^{1}$, K. R. SILVA ${ }^{1}$, E. S. DE OLIVEIRA ${ }^{1}$, M. F. S. MONTASSIER ${ }^{1}$, H. J. MONTASSIER ${ }^{2 *}$}

Um grande número de genótipos e fenótipos do VBI (sorotipos e patótipos) aparece com frequência em todo o mundo, incluindo as cepas variantes encontradas no Brasil, apesar da vacinação rotineira que acontece neste país com estirpes do VBI Massachusetts. No entanto, agrupar isolados do VBI em imunotipos é mais relevante do ponto de vista prático, porque fornece informações diretas sobre a eficácia de uma vacina contra o VBI. Cepas do VBI que induzem proteção contra o outro pertencem ao mesmo imunotipo. Neste estudo, a proteção induzida pela vacina da estirpe Massachusetts (H120) foi avaliada após o desafio com uma estirpe variante do VBI isolado no Brasil. Doze frangos LPE (livres de patógenos específicos) foram vacinados via óculo-nasal aos 21 dias de idade e desafiados com isolados de campo 21 dias pós-vacinação. Três frangos foram sacrificados aos 4, 7, 11, 14 dias pós-infecção (dpi). Os sinais clínicos foram registrados e amostras de tecidos foram coletadas da traqueia, rins e gônadas, e avaliadas quanto à presença de lesões por exame histopatológico, à carga viral por RT-qPCR, ao tropismo viral por imuno-histoquímica, e estase traqueal ciliar. Sintomas respiratórios leves foram observados em aves vacinadas e desafiadas. Além disso, a VBI foi detectada em todos os órgãos de aves vacinadas, embora as cargas virais mais elevadas estivessem presentes em rins e testículos. As lesões traqueais foram mais proeminentes entre 4-7 dpi. Os rins apresentavam uma nefrite moderada entre 4-11 dpi, e o testículo apresentou degeneração das células dos túbulos seminíferos entre 7-14 dpi. Assim, a vacina H120 promoveu apenas uma proteção parcial contra esta variante brasileira com relação à infecção da traqueia e dos rins e nenhuma proteção cruzada para a infecção dos testículos. Concluindo, este estudo caracterizou um novo imunotipo de um genótipo variante do isolado do VBI brasileiro no que diz respeito à estirpe da vacina Massachusetts, que é utilizada no Brasil atualmente.

\footnotetext{
${ }^{1}$ Programa de pós-graduação, Faculdade de Ciências Agrárias e Veterinárias - UNESP Jaboticabal, SP, Brasil.

${ }^{2 *}$ Departamento de Patologia Veterinária, Faculdade de Ciências Agrárias e Veterinárias -UNESP- Jaboticabal. E-mail: heliojm@fcav.unesp.br
} 